\title{
Terminus-driven retreat of a major southwest Greenland tidewater glacier during the early 19th century: insights from glacier reconstructions and numerical modelling
}

\author{
James M. LEA, ${ }^{1}$ Douglas W.F. MAIR, ${ }^{1}$ Faezeh M. NICK, ${ }^{2,3}$ Brice R. REA, ${ }^{1}$ \\ Anker WEIDICK, ${ }^{4}$ Kurt H. KJ $Æ R,{ }^{5}$ Mathieu MORLIGHEM, ${ }^{6}$ Dirk VAN AS, ${ }^{4}$ \\ J. Edward SCHOFIELD ${ }^{1}$ \\ ${ }^{1}$ Department of Geography and the Environment, University of Aberdeen, Aberdeen, UK \\ E-mail: j.lea@abdn.ac.uk \\ ${ }^{2}$ The University Centre in Svalbard (UNIS), Longyearbyen, Norway \\ ${ }^{3}$ Centre for Ice and Climate, Niels Bohr Institute, University of Copenhagen, Copenhagen, Denmark \\ ${ }^{4}$ Geological Survey of Denmark and Greenland (GEUS), Copenhagen, Denmark \\ ${ }^{5}$ Centre for GeoGenetics, Natural History Museum of Denmark, University of Copenhagen, Copenhagen, Denmark \\ ${ }^{6}$ Department of Earth System Science, University of California, Irvine, Irvine, CA, USA
}

\begin{abstract}
Tidewater glaciers in Greenland experienced widespread retreat during the last century. Information on their behaviour prior to this is often poorly constrained due to lack of observations, while determining the drivers prior to instrumental records is also problematic. Here we present a record of the dynamics of Kangiata Nunaata Sermia (KNS), southwest Greenland, from its Little Ice Age maximum (LIAmax) to 1859 - the period before continuous air temperature observations began at Nuuk in 1866. Using glacial geomorphology, historical accounts, photographs and GIS analyses, we provide evidence KNS was at its LIAmax by 1761 , had retreated by $\sim 5 \mathrm{~km}$ by 1808 and a further $7 \mathrm{~km}$ by 1859 . This predates retreat at Jakobshavn Isbræ by 43-113 years, demonstrating the asynchroneity of tidewater glacier terminus response following the LIA. We use a one-dimensional flowband model to determine the relative sensitivity of KNS to atmospheric and oceanic climate forcing. Results demonstrate that terminus forcing rather than surface mass balance drove the retreat. Modelled glacier sensitivity to submarine melt rates is also insufficient to explain the retreat observed. However, moderate increases in crevasse water depth, driving an increase in calving, are capable of causing terminus retreat of the observed magnitude and timing.
\end{abstract}

KEYWORDS: glacial geomorphology, glacier calving, glacier fluctuations, glacier modelling

\section{INTRODUCTION}

Tidewater glaciers (TWGs) exert a major control on the short- and long-term mass balance of the Greenland ice sheet (Van den Broeke and others, 2009; Alley and others, 2010; Bevan and others, 2012). The availability of satellite data has allowed their dynamics to be documented in detail over the past two decades (Moon and Joughin, 2008; Box and Decker, 2011; Moon and others, 2012). Prior to this, TWG dynamics are poorly constrained by observations, placing limitations on the knowledge of their response to climate change. Multi-decadal records of terminus fluctuations are available for some TWGs back to the 1930s, and limited direct observations exist before this (Bjørk and others, 2012). There is limited potential to extend TWG records to their Little Ice Age maxima (LIAmax) due to the sparse and often indirect nature of observations (Weidick, 1959, 1968; Briner and others, 2010; Larsen and others, 2011). Characterization of TWG behaviour during the 18th and 19th centuries is therefore problematic. However, where this is possible it provides insights into centennialtimescale TWG behaviour, and important context for contemporary observations and potential TWG response to future climate forcing.

Predicting the response of the Greenland ice sheet (GrIS) to climate change is dependent on understanding how TWG processes and behaviour are affected by climatic forcings
(Van den Broeke and others, 2009; Rignot and others, 2010). Although TWG stability is thought to be controlled by a combination of atmospheric and oceanic forcings occurring at the terminus, the precise processes and their relative importance are still poorly understood (Holland and others, 2008; Nick and others, 2009; Murray and others, 2010; Rignot and others, 2010, 2012; Straneo and others, 2010, 2012). Modelling of the GrIS is limited further by the short observation periods of dynamics available for calibration and validation, model computational requirements and resolution, and availability of detailed bed topography (Vieli and Nick, 2011). These can be mitigated by employing spatially reduced models to evaluate glacier catchmentscale responses to different forcings (Thomas, 2004; Nick and others, 2009, 2010, 2012, 2013; Joughin and others, 2010a; Colgan and others, 2012). Application of these models where TWG records can be extended to their LIAmax allows the potential drivers of post-LIAmax GrIS retreat to be investigated.

The earliest post-LIAmax TWG retreats in Greenland are known to have occurred prior to the first continuous air temperature record at Nuuk in 1866 (Weidick, 1959, 1968; Vinther and others, 2006; Weidick and others, 2012). This can preclude direct comparison of post-LIAmax TWG response to climate, including the first observed retreat of Jakobshavn Isbræ between 1851 and 1875 (Weidick and 


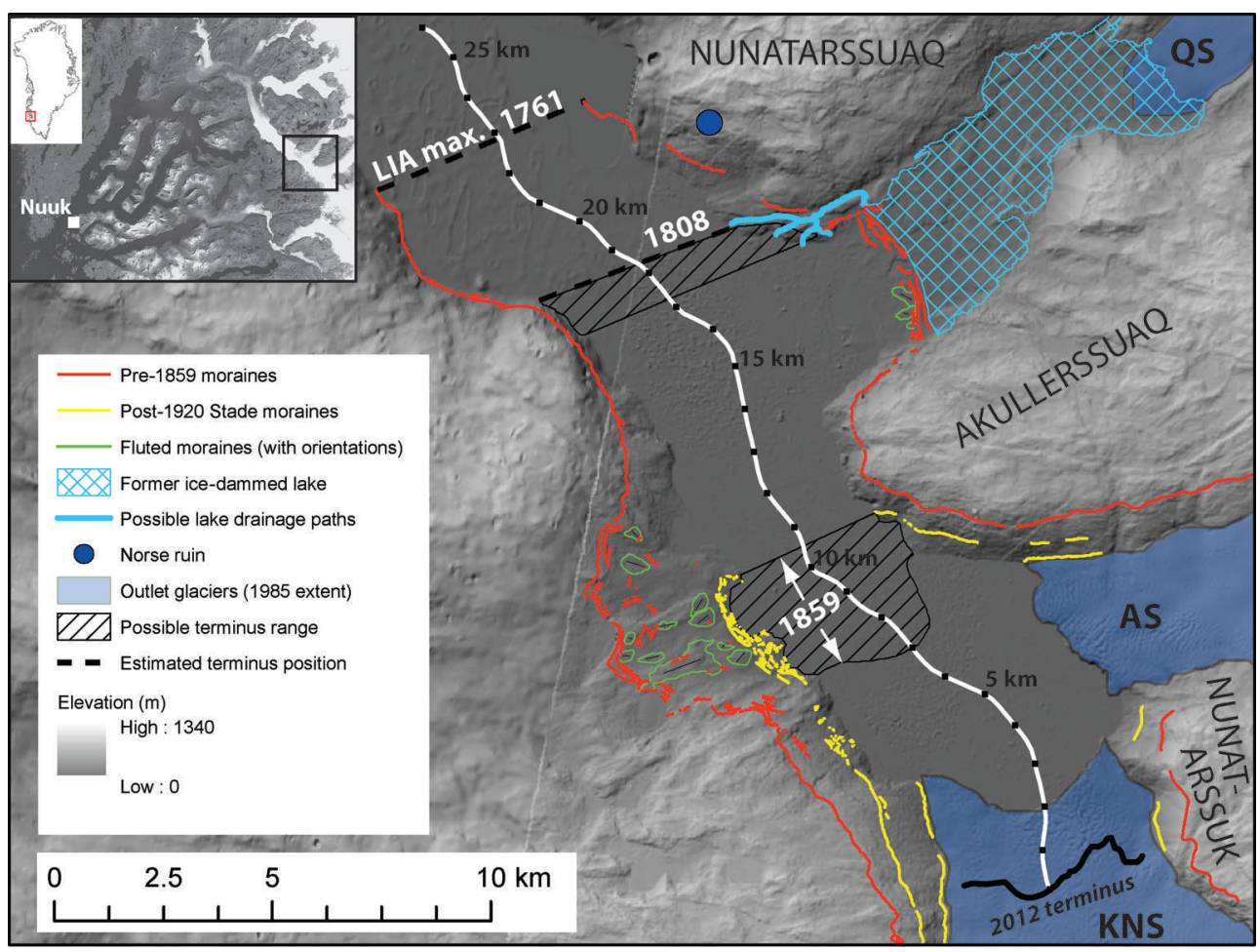

Fig. 1. Hillshaded digital elevation model (photogrammetric DEM and ASTER GDEM mosaic), showing the post-LIAmax geomorphology, and the possible terminus positions/ranges relative to the 2012 terminus position. The 2012 terminus position was mapped from a Landsat image acquired on 18 September 2012. Minimum extent for 1859 position is taken from 1946 terminus position, observed prior to disintegration of the confluence by 1948 (Weidick and Citterio, 2011). Inset is a panchromatic Landsat image of the Godthåbsfjord region acquired on 19 September 1992.

Bennike, 2007; Csatho and others, 2008). Application of catchment-scale models where climate data are lacking allows the drivers of individual TWG change to be investigated through series of model sensitivity experiments. These facilitate comparisons of modelled behaviour to observations, and can be used to identify the range of forcings and likely mechanism(s) required to explain the observed retreat.

This study investigates the post-LIAmax dynamics of Kangiata Nunaata Sermia (KNS), southwest Greenland, prior to the instrumental air temperature record. We aim to improve the record of post-LIAmax fluctuations of KNS using previously unstudied geomorphology, newly uncovered historical sources, geospatial analyses, and previously published lines of evidence (Weidick, 1959; Weidick and others, 2012). Secondly, we evaluate whether the postLIAmax retreat is best explained by changes in surface mass balance $(\mathrm{SMB})$ or forcing perturbations occurring at the terminus. This is achieved using a one-dimensional (1-D) flowband numerical model (Nick and others, 2010).

\section{FIELD SITE}

KNS is located $\sim 100 \mathrm{~km}$ from Nuuk at the head of the Kangersuneq branch of Godthåbsfjord, southwest Greenland (Fig. 1). The terminus retreated significantly during the 19th century, though uncertainty exists regarding the timing and scale of this retreat (Weidick, 1959; Weidick and others, 2012). The glacier catchment is $\sim 31400 \mathrm{~km}^{2}$, and has a contemporary calving flux in excess of $6 \mathrm{~km}^{3} \mathrm{a}^{-1}$, making it the largest outlet glacier in western Greenland located south of Jakobshavn Isbræ (Van As and others, 2014). At its LIAmax, KNS was advanced $>22 \mathrm{~km}$ further down-fjord of its current terminus position, occupying a topographic depression on the west side of the fjord, and forming a large icedammed lake (IDL) in the forefield of Qamanarssup Sermia (QS; Weidick and others, 2012).

Subsurface West Greenland Current (WGC) waters periodically enter Godthåbsfjord over a shallow $(80 \mathrm{~m})$ sill at the entrance to the fjord, establishing a link between the ocean and the terminus (Mortensen and others, 2011, 2013). Fjord circulation allows surface heated waters to mix downward to subsurface fjord waters, which can also interact with the terminus (Mortensen and others, 2011). No direct measurements of submarine melt (SM) exist for KNS, although estimates of SM at vertical calving fronts of other West Greenland TWGs range from $0.7 \pm 0.2$ to $3.9 \pm 0.8 \mathrm{~m} \mathrm{~d}^{-1}$ (Rignot and others, 2012). Within this range, SM for KNS is probably at the lower end due to the sill at the fjord entrance limiting the ability of warm WGC waters to reach the terminus (Straneo and others, 2012).

\section{METHODS FOR RECONSTRUCTING AND DATING GLACIER TERMINUS POSITIONS}

The LIAmax extent of KNS is clearly defined by a series of moraines and ice-scour limits (Weidick and Citterio, 2011; Weidick and others, 2012). These limits and the geomorphology inside were mapped in detail using highresolution $\left(2 \mathrm{~m}^{2}\right)$ GeoEye satellite imagery, and groundtruthed during fieldwork conducted in 2011. Reconstructions of glacier geometry were obtained by extracting elevations of mapped moraine limits from an aerophotogrammetrically derived digital elevation model (DEM) of the KNS terminus area, based on a 1985 aerial survey 


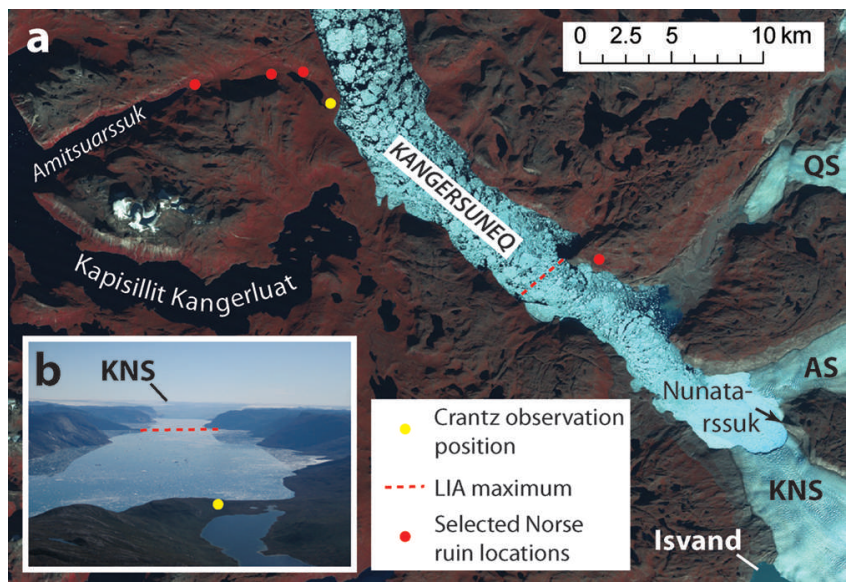

Fig. 2. Approximate reconstructed location position of Crantz (1820) from which he observed KNS in 1761. (a) False-colour Landsat image (acquired 15 September 1987) showing location information. (b) Photograph taken from helicopter in August 2011 showing view down Kangersuneq looking towards the southeast, approximating the view of Crantz.

conducted by the Danish Geodata Agency with associated ground control (GR96) and error of $\pm 6 \mathrm{~m}$. Where coverage from this DEM was unavailable, Advanced Spaceborne Thermal Emission and Reflection Radiometer (ASTER) global DEM (GDEM) data (http://asterweb.jpl.nasa.gov/gdem.asp) gridded to $30 \mathrm{~m}^{2}$ resolution were used (Fig. 1). Moraine elevations were extracted relative to the glacier/fjord centre line (also used as the model flowline) using the extrapolated centre-line method presented in Lea and others (2014). This allowed moraine elevation profiles to be directly and accurately compared to the modelled glacier elevation profiles (e.g. Fig. 9, further below).

The date and location of terminus positions were reconstructed using an array of historical sources, which are discussed in detail below. The physical plausibility of each account was tested where possible, to establish the level of confidence that could be placed in each observation. In some cases, GIS tools could be applied to constrain terminus locations with greater absolute precision than allowed by qualitative analysis alone.

\section{Historical accounts}

The earliest terminus position of KNS that can be determined is from the observations of David Crantz in 1761 (published in English in 1820). He describes observing an unnamed glacier in Baal's Rivier (a previous name for Godthåbsfjord and Kangersuneq) that 'ascends in steps for the space of four leagues $[\sim 22 \mathrm{~km}]^{\prime}$, while '[a] low hill ... closed the vista', and 'large tracts of ice ... branched off north and south to an unknown distance into the country' (Crantz, 1820, p. 34). Crantz's viewpoint has been reconstructed to be from the valley separating Kangersuneq and Amitsuarssuk fjord branches (Fig. 2). This is based on his account of his approach to the observation point, describing hiking along a valley through which flowed a 'rivulet, swelling at intervals into pools', and with Norse ruins located adjacent to 'a great lake of freshwater' (Crantz, 1820, p.33). The valley identified is the only one in the region that fits Crantz's description (Fig. 2a). KNS is also the only observable TWG from this viewpoint, with Nunatarssuk likely to be the low hill mentioned, located $20 \mathrm{~km}$ from LIAmax (Fig. 2b).

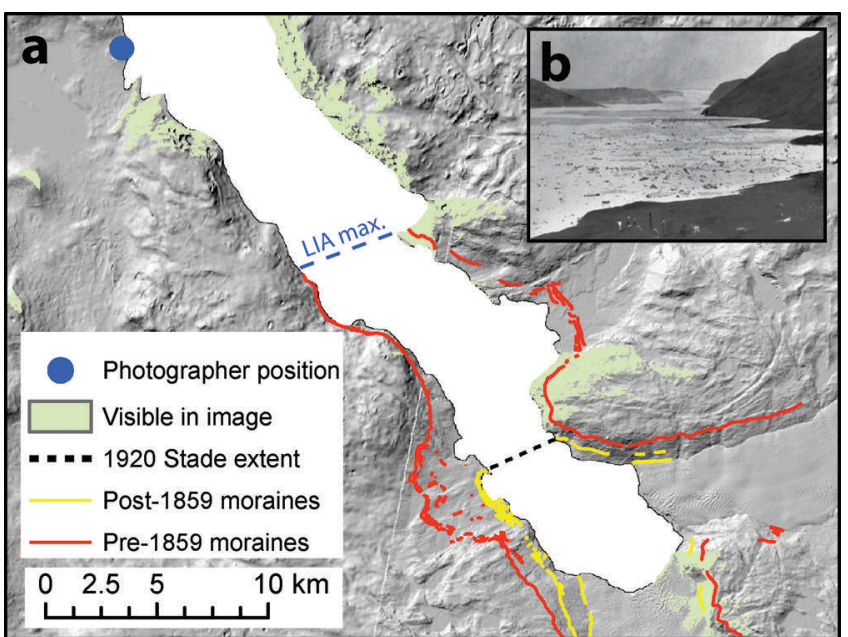

Fig. 3. Viewshed analysis of image acquired during the 1850s. (a) Hillshaded DEM showing the area visible to an observer standing at the location indicated, and (b) the image of KNS taken in the 1850s by Rink (from Weidick and others, 2012).

The next reference to KNS is from Egil Thorhallesen, who, guided by locals, visited an IDL between 1765 and 1775 previously identified as Isvand (Fig. 2; Weidick, 1959; Weidick and others, 2012). The account does not relate a direct observation of the terminus, though it is of potential relevance since the ice margin position at Isvand was dynamically linked to the terminus retreat of KNS during the 20th century (Weidick and Citterio, 2011). The wording of Thorhallesen's account is ambiguous in that it reports that 'the glacier has laid itself in recent time' over Isvand (Thorhallesen, 1776 , p. 37). This makes it unclear whether he is referring to a recent advance or retreat of the ice margin from its observed position.

The diaries of Karl Ludwig Giesecke record a visit made to the terminus area of KNS in August 1808 (published in German in 1910). He describes the ice having nearly overridden the Norse ruins indicated in Figure 1 at its maximum extent, though the retreated terminus is still nearby. He makes a comparative assessment of the glacier geometry as being 'grösser, steiler, und gefährlicher als der Nordöstliche' (larger, steeper and more dangerous than that to the north-east [Qamanarssap Sermia]; trans. by N. Weitz) (Giesecke, 1910, p. 151), and describes an IDL occupying the QS forefield which 'über die Felsenwand hinab am Eisblink ins Meer stürzt' (next to the glacier flows over a rock wall into the ocean; trans. by N. Weitz) (Giesecke, 1910, p. 151).

\section{Maps and photographic evidence}

The first map of Godthåbsfjord from which it is possible to obtain a reliable estimate of the terminus position of KNS was drawn by Samuel Kleinschmidt (Kleinschmidt, 1859). This shows KNS and AS to be confluent, with the terminus adjoining Akullerssuaq (Fig. 1). An earlier map by Heinrich Rink (Rink, 1856) shows KNS to be in a similarly retreated position, though the absence of the valley separating Nunatarssuaq and Akullerssuaq does not allow relative terminus position in the fjord to be identified with confidence. A photograph taken by Rink during the 1850s (in Weidick and others, 2012) shows AS and KNS to be confluent (as evidenced by the presence of a medial moraine), though the terminus itself is partially obscured by 


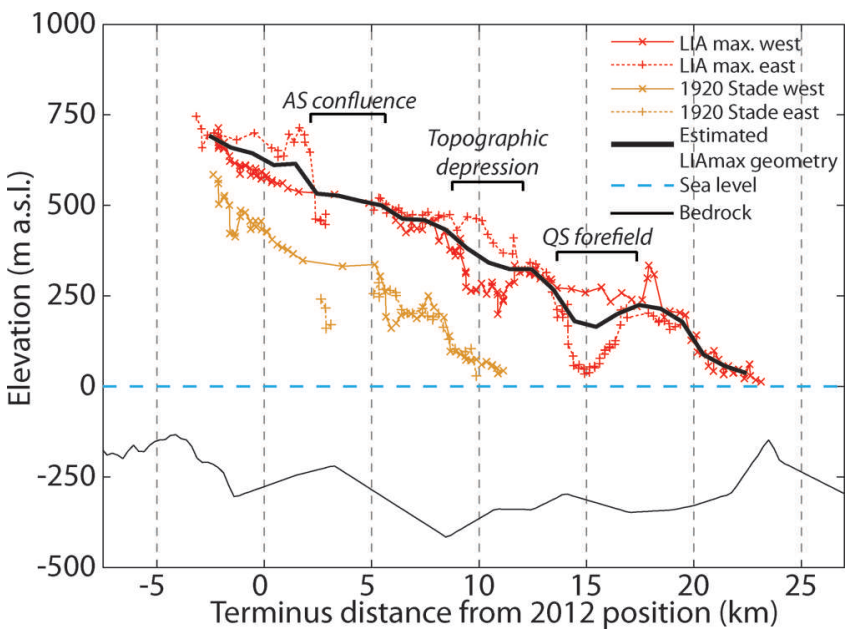

Fig. 4. LIA and 1920 Stade trimline elevations acquired from the DEM. Locations of significant changes in topography and the confluence of KNS with AS are labelled. LIAmax geometry is estimated by averaging the western and eastern trimline elevations over $1 \mathrm{~km}$ ranges.

foreground topography (Fig. 3b). This prevents the identification of the exact position of the terminus from this image.

\section{RESULTS}

\section{Post-LIAmax geomorphology}

Figure 1 shows the post-LIAmax geomorphology of KNS. All subsequent mentions of glacier terminus positions are given relative to the 2012 terminus, indicated by the fjord centre line (Fig. 1). The maximum moraine/ice-scour extent is $22.6 \mathrm{~km}$, and covers an area $220 \mathrm{~km}^{2}$ greater than at present. Multiple sets of moraines exist on both flanks of the fjord within the LIAmax. These include:

An upper set of well-developed continuous lateral moraines/ice scour on both sides of the fjord delimiting the LIAmax. On the eastern fjord flank the moraine spans the forefield area of the land-terminating glacier Qamanarssup Sermia (QS), while the moraine on the western flank extends inland into the topographic depression opposite Akullerssuaq (Fig. 1).

Several other less pronounced moraines lie proximal and sub-parallel to well-developed upper moraines in the QS forefield on the eastern flank, and also within the topographic depression opposite Akullerssuaq on the western flank. Fluted moraines occupy areas within the LIAmax extent of the QS forefield and between the LIAmax and 1920 Stade moraines on the western flank. These are broadly orientated according to the slope of local topography (Fig. 1).

A lower set of moraines/ice scour extends to $\sim 10 \mathrm{~km}$ along both sides of the fjord. On the eastern flank this wraps around Akullerssuaq, and on the less steep western flank several inset sub-parallel moraines are present. The outer limit of these has previously been related to the culmination of the 1920 Stade readvance (Weidick and Citterio, 2011).

Trimline elevations show that glacier surface elevation from $\sim 20 \mathrm{~km}$ to the LIAmax extent did not exceed $100 \mathrm{~m}$ a.s.l., with an average surface gradient of $1.6^{\circ}$ (Fig. 4). The glacier surface significantly steepens upstream between 20 and $18 \mathrm{~km}$ to $4.2^{\circ}$, before surface elevation appears to decrease where the QS forefield adjoins Kangersuneq between 14 and $18 \mathrm{~km}$ (Fig. 4). The ice surface steepens to $3.6^{\circ}$ as the fjord narrows between 12 and $14 \mathrm{~km}$, before levelling out between 10 and $12 \mathrm{~km}$ opposite Akullerssuaq as the ice extends into the topographic depression (Figs 1 and 4). The ice surface rises by $\sim 200 \mathrm{~m}$ between 2 and $10 \mathrm{~km}\left(1.4^{\circ}\right.$ surface slope), with the gradient doubling to $2.8^{\circ}$ between 1 and $2 \mathrm{~km}$, reaching an elevation of $\sim 600 \mathrm{~m}$ a.s.l. This final elevation step change occurs immediately upstream of the confluence with AS (Fig. 4).

\section{Reconstructing timing of terminus fluctuations: LIAmax-1859}

The account of Crantz describing KNS extending from Nunatarssuk for $\sim 20 \mathrm{~km}$ corresponds almost exactly with the LIAmax extent of the glacier (Figs 2 and 3). His description of the glacier profile as 'ascending in steps' (1820, p. 34) also fits with the reconstructed LIAmax geometry of KNS, with at least three changes in surface gradient identified (Fig. 4). It is proposed that Crantz observed KNS at or very near its LIAmax extent in 1761.

Giesecke's (1910) description of an IDL draining directly over land into the fjord provides excellent constraint on the terminus position in 1808. For this drainage to occur, the eastern margin of KNS must be sufficiently retreated from LIAmax to allow the IDL to drain into the fjord over land, rather than subglacially or as an ice-marginal channel. To establish the terminus configurations where it is physically possible to maintain an IDL in the QS forefield, which also drains into the fjord over land, an analysis of possible lake drainage pathways was conducted using the ArcHydro addon to ArcMap v.10 software. Using the DEM shown in Figure 1, dams were inserted along the LIAmax moraines spanning the QS forefield, allowing the IDL and its drainage paths to be reconstructed. Four possible land drainage paths could maintain the IDL, located within a terminus range of $\pm 550 \mathrm{~m}$ (Fig. 1). However, since the majority of this range is within a section of the fjord that begins to widen, from a glaciological perspective the narrower section of the fjord represents a more likely location for the terminus (Mercer, 1961). The 1808 terminus location on the western flank is less certain, though a likely range of terminus configurations is indicated in Figure 1.

The smaller, less continuous inset moraines subparallel to the LIAmax suggest glacier thinning from the LIAmax. The steep fjord valley side topography that extends between 17 and $22 \mathrm{~km}$ provides low preservation potential for moraines, meaning that the style of retreat from 1761 to 1808 cannot be reconstructed with confidence.

Map evidence places the terminus of KNS as adjoining Akullerssuaq in 1859 (Kleinschmidt, 1859). Viewshed analysis applied to the photograph taken by Rink in the 1850 s (Rink, 1856) allows the maximum possible extent of the terminus to be reconstructed (Fig. 3). From this, the headland that partially obscures the terminus in this photograph corresponds to the 1920 Stade moraine limit. The terminus was therefore located inside this limit by 1859 (Fig. 1).

In the topographic depression opposite Akullerssuaq (Fig. 1), the geomorphology preserves no evidence for stabilization of the lateral ice margin between the LIAmax/ LIAmax-proximal and 1920 Stade lateral moraines. This is 
despite the shallow slope of this area providing excellent potential to preserve moraines. The presence of fluted moraines in this area suggests that reworking has not been significant, making the destruction of lateral moraines highly unlikely. The ice margin is therefore interpreted to have thinned rapidly, in a single phase, bringing it inside the 1920 Stade moraine extent.

In summary, KNS had achieved its LIAmax by 1761, and subsequently retreated rapidly in either one or two phases. In the single-phase scenario, Giesecke (1910) observed the terminus part way through the retreat in 1808. Lack of evidence for stabilization of the lateral ice margin indicates retreat to its 1859 position would have occurred rapidly (i.e. in years rather than decades). The two-phase scenario would have KNS retreating and temporarily stabilizing at or near its 1808 extent between 1761 and 1808, forming the inset lateral moraines adjacent to those of the LIAmax, before retreating rapidly to its 1859 position sometime between 1808 and 1859.

\section{MODEL EXPERIMENTS}

The aim of the model experiments is to determine the likely drivers of the reconstructed terminus retreat. Three sets of experiments were run, aiming to test (1) the sensitivity and response timescales of KNS to a range of step changes in $\mathrm{SMB}$, (2) sensitivity to direct forcing of the terminus, including incremental increases in crevasse water depth (CWD), and submarine melt rates (SM), and (3) the response timescales following step changes in terminus forcing. Parameter sensitivity was tested over significant ranges of values to allow full characterization and evaluation of model behaviour. For each model run, the glacier was tuned to approximate the reconstructed LIAmax geometry (e.g. Figs 2 and (further below) 9), using the process described in Appendix B.

\section{Model description and input}

KNS is modelled using a 1-D depth-integrated flowband model (Nick and others, 2010), utilizing a crevasse-depth calving criterion, where calving occurs once the combined basal and surface crevasses penetrate the full ice thickness (Benn and others, 2007; Nick and others, 2010). The CWD variable within this criterion has previously been used to drive models, linking it to air temperature or runoff data (Cook and others, 2012, 2013; Nick and others, 2013), while submarine melting (SM) can be applied as negative mass balance downstream of the grounding line (Nick and others, 2013). Experiments are run using a moving grid, with an along-flow grid size of $\sim 250 \mathrm{~m}$. The model has previously been applied successfully to several different TWGs in Greenland (Nick and others, 2009, 2012, 2013; Vieli and Nick, 2011). A description of the force-balance equations and calving criterion are provided in Appendix A, and the parameter values used are presented in Table 1.

Basal topography for the lower $40 \mathrm{~km}$ of the catchment is derived using a mass continuity approach following the methodology of Morlighem and others (2011), utilizing CReSIS (Center for Remote Sensing of Ice Sheets, University of Kansas, USA) flight lines for validation (Gogineni and others, 2001). For the upper catchment, bed topography is obtained from Bamber and others (2001). Point measurements of fjord bathymetry were used for bed topography in Kangersuneq, where KNS terminates (Fig. 4; Weidick and
Table 1. List of parameters and constants used to run the model

\begin{tabular}{lc} 
Parameter/constant & Value \\
\hline Ice density, $\rho_{\mathrm{i}}$ & $900 \mathrm{~kg} \mathrm{~m}^{-3}$ \\
Meltwater density, $\rho_{\mathrm{w}}$ & $1000 \mathrm{~kg} \mathrm{~m}^{-3}$ \\
Proglacial water body density, $\rho_{\mathrm{p}}$ & $1028 \mathrm{~kg} \mathrm{~m}^{-3}$ \\
Gravitational acceleration, $g$ & $9.8 \mathrm{~m} \mathrm{~s}^{-2}$ \\
Friction exponent, $m$ & 3 \\
Friction parameters, $\mu$ and $\lambda$ & 1 \\
Glen's flow law exponent, $n$ & 3 \\
Glen's flow law coefficient, $A$ & $4.5 \times 10^{-17} \mathrm{~Pa}^{-3} \mathrm{a}^{-1}$ \\
Grid size & $\sim 250 \mathrm{~m}^{2}$ \\
Time-step & $0.005 \mathrm{year}$
\end{tabular}

others, 2012). Model sensitivity to bed topography uncertainty is evaluated by experiments outlined in Appendix C. SMB ablation values are taken from the average 19582007 Regional Atmospheric Climate Model (RACMO) output for the catchment of KNS (Ettema and others, 2009). The overall SMB results in contemporary balance calving flux of $\sim 8.2 \mathrm{~km}^{3} \mathrm{a}^{-1}$, well in excess of the direct contemporary estimates of $\sim 6 \mathrm{~km}^{3} \mathrm{a}^{-1}$ (Van As and others, 2014). SMB values in the accumulation zone are therefore reduced, so as to maintain the contemporary ice-sheet elevation over centennial-timescale model runs.

This represents a conservative approach to the definition of accumulation SMB values during the LIA, since values have been suggested to be $\sim 10-40 \%$ lower over the catchment of KNS during this period (Box and others, 2013). The definition of catchment boundaries in the icesheet interior, which can affect apparent calving fluxes in the long term, is also known to represent a potentially significant uncertainty when defining the accumulation zone of an icesheet glacier (Van As and others, 2012, 2014). However, high-resolution SMB modelling of the Nuuk region for 1960-present also indicates that most of the interannual variability in the net balance of KNS's catchment is derived from changes in ablation, where the catchment is likely to be comparatively well defined (Van As and others, 2014). Therefore most of the SMB-driven mass change over the period of interest is likely to have been driven by variability in the ablation zone rather than by changes in accumulation.

Ice contributed by Akullerssup Sermia (AS), the glacier adjacent to KNS, is accounted for in the model as extra SMB across their $5 \mathrm{~km}$ confluence (between 3 and $8 \mathrm{~km}$ ). The flux is distributed along this confluence proportional to the contemporary across-terminus velocity profile of AS (Joughin and others, 2010b). An approximation of the present-day flux of AS is derived by taking a physically based estimate of the flux of KNS of $\sim 6 \mathrm{~km}^{3} \mathrm{a}^{-1}$ (Van As and others, 2014), and scaling this value using the widths and terminus velocities of both glaciers. This provides a contemporary AS flux estimate of $\sim 1 \mathrm{~km}^{3} \mathrm{a}^{-1}$. In the model the volume of ice contributed by AS per time-step is therefore taken to be one-sixth of the modelled flux of KNS immediately upstream of their confluence.

Modelled terminus positions were compared directly to mapped terminus positions using the curvilinear box method (CBM) of tracking terminus change (Lea and others, 2014). This allows direct comparison of mapped results to model results since both the $\mathrm{CBM}$ and the model track terminus position in relation to the fjord centre line. 

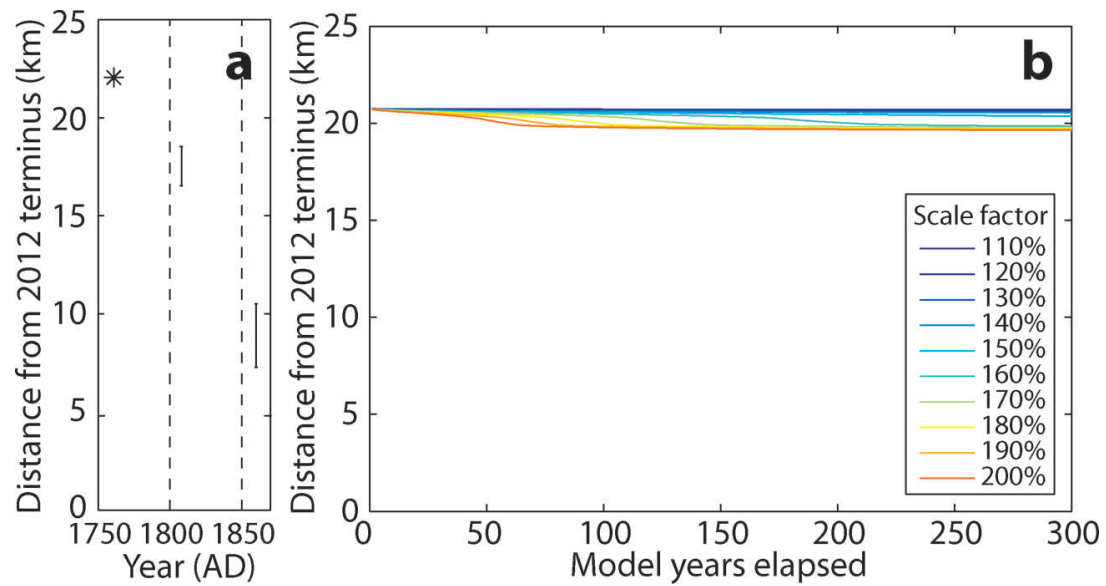

Fig. 5. Results showing (a) observed terminus retreat, and (b) modelled retreat showing impact of multiplying ablation rates by a prescribed scale factor. Model was spun up to be vulnerable to retreat near its LIA maximum, with CWD $=175 \mathrm{~m}$ and no SM applied.

\section{Sensitivity to surface mass balance}

All SMB experiments were run keeping terminus forcing (CWD and SM) constant (Fig. 5). These experiments test terminus sensitivity to step changes in ablation zone SMB up to $200 \%$ of the $1958-2007$ RACMO average values. Sensitivity to step changes in accumulation was not investigated, due to the likelihood of accumulation having increased over the glacier catchment following the LIA (Box and others, 2012). Separate model runs were conducted for $10 \%$ increments of initial SMB ablation values ranging between $110 \%$ and $200 \%$. Sensitivity was evaluated by comparing the model time required for the terminus to retreat, to the known time needed, indicated by the glacier reconstruction.

\section{Sensitivity to forcing at the terminus}

Glacier sensitivity to terminus forcing is investigated through application of both incremental and step changes in forcing. The sensitivities of LIAmax KNS to incremental changes in both CWD and SM were evaluated separately to characterize how, or if, they responded differently to small, steady increases in these two forcings. Two sets of model runs with incremental forcing were conducted. The first increased CWD by $1 \mathrm{~m}$ every fifth year of the model run, while SM was held constant, testing terminus sensitivity to CWD for fixed values of SM. The second increased SM from initial predefined values $\left(0-1.5 \mathrm{~km}^{3} \mathrm{a}^{-1}\right.$, at $0.1 \mathrm{~km}^{3} \mathrm{a}^{-1}$ intervals) by $0.025 \mathrm{~km}^{3} \mathrm{a}^{-1}$ every fifth year, while CWD was held constant. By doing this we evaluate terminus sensitivity to small successive increases in SM from given initial SM scenarios at the LIAmax, and constant CWD values.

Glacier sensitivity to different magnitudes of step change in CWD was evaluated by applying these for different constant SM values in each model run. SM values used were determined from the results of the incremental forcing experiments, using only values where modelled retreat behaviour was comparable to the pattern of retreat observed. Experiments were also conducted in which different magnitudes of step change in SM were applied. Similar to the SMB experiments, sensitivity was evaluated by comparing the model time required for the terminus to retreat following the step change, to the known timescale of glacier retreat.

\section{MODEL RESULTS}

The modelled evolution of the terminus position is shown with respect to time (Figs 5, 7 and 8) and forcing applied (Fig. 6). The locations of modelled stable terminus positions driven by SM and CWD forcings are replicated between
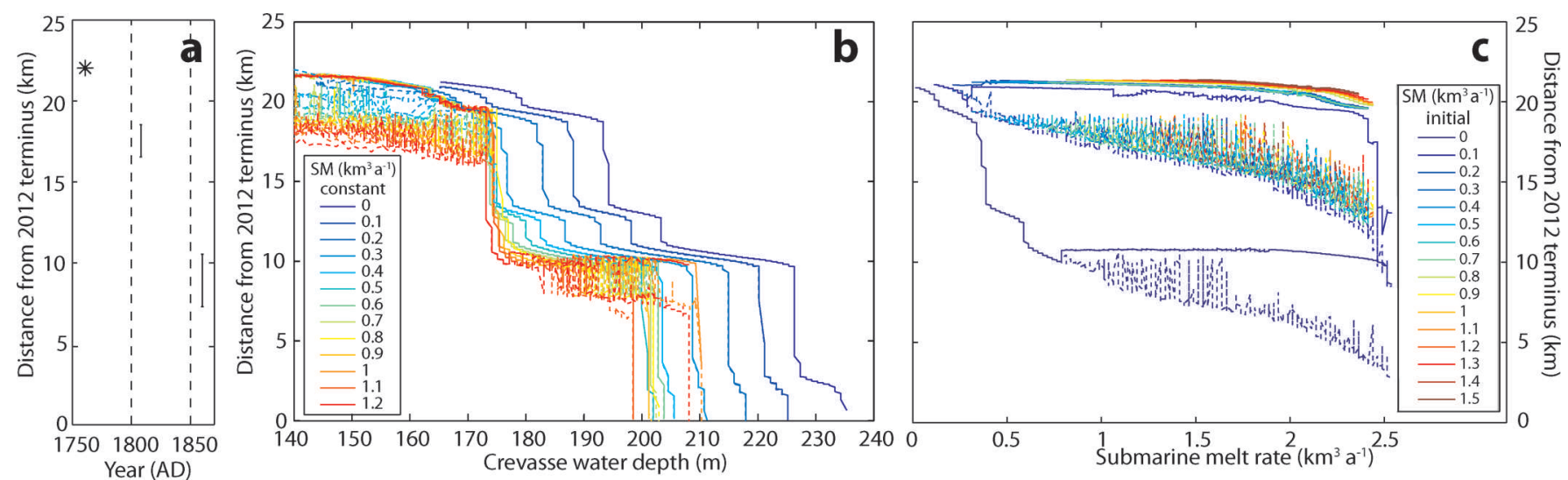

Fig. 6. Results showing (a) observed terminus retreat, (b) modelled retreat holding SM constant and increasing CWD by $1 \mathrm{~m}$ every fifth modelled year, and (c) modelled retreat holding CWD constant, after spinning up to an initial SM at LIAmax, and increasing SM by $0.025 \mathrm{~km}^{3} \mathrm{a}^{-1}$ every fifth modelled year. Narrow dashed curves in (b) and (c) indicate position of the grounding line. 

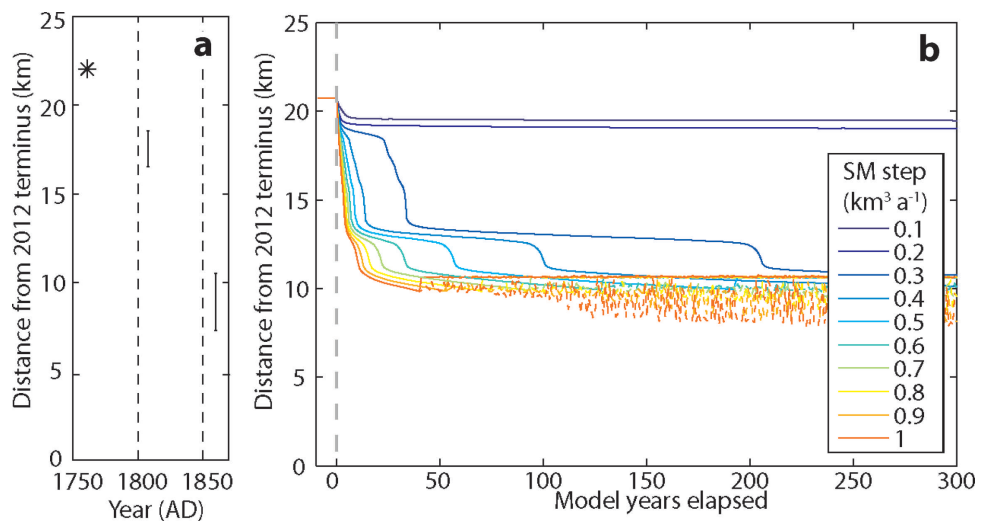

Fig. 7. Model results showing (a) observed terminus retreat and (b) terminus position following a step change in SM following a 50 year spinup period where $S M=0 \mathrm{~km}^{3} \mathrm{a}^{-1}$, following the results of the incremental sensitivity tests. CWD is held constant throughout (175 m). Dashed lines indicate position of the grounding line. Application of the step change in each case occurs at 0 years (bold dashed line).

experiments (Fig. 6). The majority of model runs also simulate some degree of stabilization at a topographic narrowing in the fjord at $\sim 12.5 \mathrm{~km}$ from the 2012 terminus position, where there is no observational or geomorphological evidence of terminus stabilization (Fig. 6). This potential pinning point is thought to be real, rather than an artefact of bed topography uncertainty (Appendix C). Each modelled stable terminus position possesses different relative resilience to increasing levels of forcing before retreating to the next stable location. Of the pinning points identified, the $12.5 \mathrm{~km}$ position is generally the least resilient to changes in forcing.

\section{SMB forcing}

The modelled glacier displays very little sensitivity to changes in ice thickness driven by changes in ablation (Fig. 5). Even an extreme SMB forcing (ablation $=200 \%$ of 1958-2007 RACMO average) produces a retreat $<1 \mathrm{~km}$ from the LIAmax over 300 model years. It is therefore unlikely that SMB-driven changes in ice thickness caused the retreat from LIAmax to the 1808 position.

\section{Incremental terminus forcing}

Model results of incremental forcing demonstrate that CWD and SM can potentially initiate rapid terminus retreat over small parameter spaces (Fig. 6). However, the sensitivity of the modelled glacier to the absolute values of SM or CWD is dependent on the initial conditions of the model run. Model runs with higher SM rates enhance the sensitivity of the modelled glacier to changes in CWD, with the $12.5 \mathrm{~km}$ pinning point becoming less well represented as SM increases (Fig. 6b). Although this pinning point is barely apparent where $S M>0.8 \mathrm{~km}^{3} \mathrm{a}^{-1}$ (demonstrating behaviour in agreement with the glacier reconstruction presented), these represent SM rates at the upper end, or greater than anything previously observed in Greenland (Rignot and others, 2012; Enderlin and Howat, 2013). These runs also generate instabilities within the model, with the grounding line demonstrating significant oscillatory behaviour $(>1 \mathrm{~km})$ over timescales of $<1$ year (Fig. 6b).

Only one model run, spun up to the LIAmax with $S M=0 \mathrm{~km}^{3} \mathrm{a}^{-1}$, retreated significantly in response to increasing SM (Fig. 6c). Remaining model runs formed floating ice tongues, as high SM rates drove grounding line retreat, while there was sufficient lateral drag for the terminus to remain stable. If increasing SM did drive retreat from LIAmax to the 1920 Stade position, it would have required SM to have dramatically increased, from $0 \mathrm{~km}^{3} \mathrm{a}^{-1}$ to $\sim 0.6 \mathrm{~km}^{3} \mathrm{a}^{-1}$. However, this run also includes the terminus stabilizing at the $12.5 \mathrm{~km}$ pinning point, not represented in the glacier reconstruction. Once $S M>0.78 \mathrm{~km}^{3} \mathrm{a}^{-1}$ the model run begins to display comparable grounding line variability to that observed in other runs where initial SM rates were $>0 \mathrm{~km}^{3} \mathrm{a}^{-1}$ (Fig. 6c).

\section{Step changes in terminus forcing}

Following results from incremental increases in SM (Fig. 6c), step changes in SM of different magnitudes were applied only where the model was spun up with an initial SM rate of $0 \mathrm{~km}^{3} \mathrm{a}^{-1}$ at the LIAmax (Fig. 7). The results from these runs demonstrate that an increase in SM to $0.3 \mathrm{~km}^{3} \mathrm{a}^{-1}$ could cause a retreat to the 1859 terminus position, though it would take $>200$ years to do so. To drive a retreat from the LIAmax to the 1859 position within the time frame observed (<98 years), requires a step-change increase of at least $0.5 \mathrm{~km}^{3} \mathrm{a}^{-1}$. However, given the lack of geomorphological evidence for a stable margin at $12.5 \mathrm{~km}$, an increase of $>0.6 \mathrm{~km}^{3} \mathrm{a}^{-1}$ would probably be required, based on the modelled time needed for the terminus to retreat through the $12.5 \mathrm{~km}$ pinning point (Fig. 7).

Step changes in CWD of $10 \%$ (Fig. 8a) and 20\% (Fig. 8b) were also applied for constant SM ranging from 0.1 to $1 \mathrm{~km}^{3} \mathrm{a}^{-1}$. As with results from incremental changes in CWD (Fig. 6b), these show that terminus sensitivity to changes in CWD increases with higher values of SM (Fig. 8). However, results also demonstrate that moderate step changes in CWD are capable of producing a retreat to the 1859 position for moderate values of SM. For example, where $S M>0.3 \mathrm{~km}^{3} \mathrm{a}^{-1}$, a $20 \%$ increase in CWD can drive a retreat from LIAmax to the 1859 position in 31 years.

\section{IMPLICATIONS OF MODEL RESULTS}

Model results demonstrate that the LIAmax to 1859 retreat of KNS is unlikely to have been driven by changes in SM or SMB. Where changes in SM can produce a retreat pattern comparable to that observed (Figs $6 \mathrm{c}$ and 7 ), the SM rates required to achieve this are at the upper end, or greater than anything previously observed in Greenland (Rignot and others, 2012; Enderlin and Howat, 2013). The step changes in SM required to reproduce observed retreat that skip the $12.5 \mathrm{~km}$ pinning point are also of such a scale (increasing 

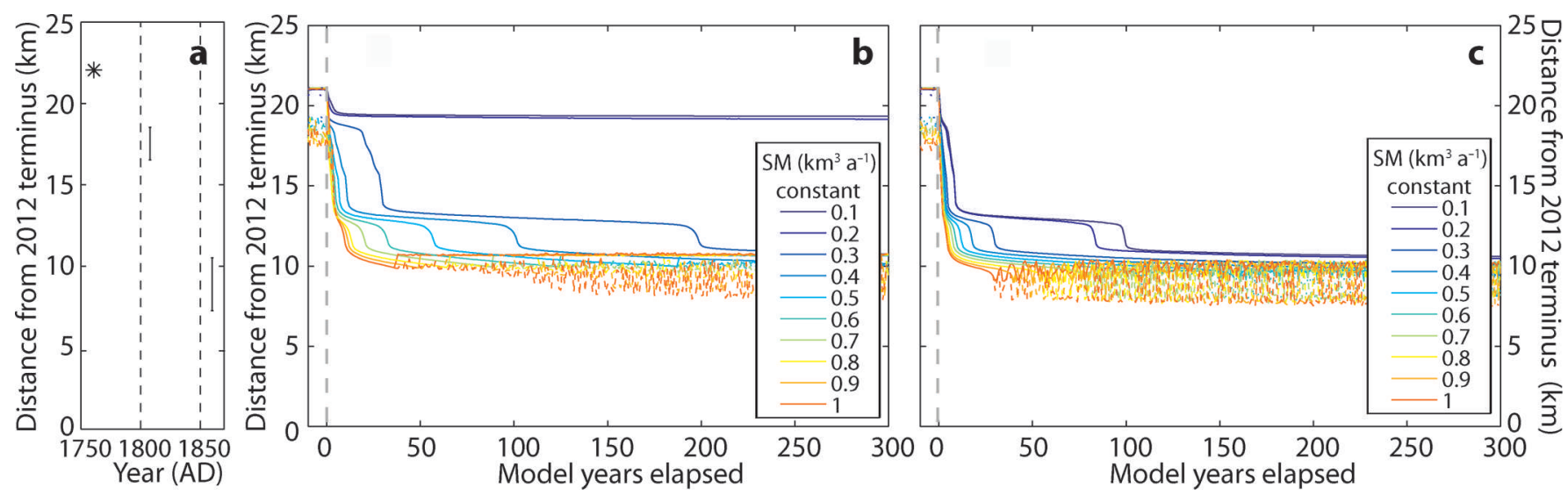

Fig. 8. Model results showing (a) observed terminus retreat, and (b, c) terminus positions following a $10 \%$ (b) and $20 \%$ (c) step change in CWD after a 50 year spin-up period. Narrow dashed curves in (b) and (c) indicate position of the grounding line. Application of the step change in each case occurs at 0 years (bold dashed line).

from 0 to $\sim 0.8 \mathrm{~km}^{3} \mathrm{a}^{-1}$ ), that they are equivalent to the SM regime at KNS changing from experiencing one of the lowest, to one of the highest SM rates currently observed in Greenland. For this to occur would necessitate a dramatic change in fjord hydrography. Such a change is thought to be not only unlikely, but also unrealistic, given observations of the contemporary fjord hydrography (Mortensen and others, 2011, 2013), and the likelihood of KNS experiencing low SM rates compared to the rest of Greenland (Straneo and others, 2012).

In comparison, results from experiments with step changes in forcing demonstrate that moderate changes in CWD are capable of replicating the observed pattern of retreat, within a realistic time frame (Fig. 8). Crucially, these are observed where the model is run with comparatively low SM rates $\left(>0.3 \mathrm{~km}^{3} \mathrm{a}^{-1}\right)$. These SM values fall well within the range of SM rates that have been observed for vertical calving fronts elsewhere in Greenland (equivalent to between $(0.15 \pm 0.05)$ and $(0.8 \pm 0.15) \mathrm{km}^{3} \mathrm{a}^{-1}$ for KNS; Appendix A).

The changes in CWD required to drive this retreat are also consistent with variability from high-resolution SMB modelling of KNS for the period 1960-2011 (Van As and others, 2014). For this period, significant interannual variability in runoff is shown to exist, with values of $3.12 \pm 2.40 \mathrm{Gta}^{-1}$ ( $2 \sigma$, representing interannual variability of $\pm 77 \%$ ). Longerterm averages of modelled runoff values also display significant variability. For example, modelled runoff for the period $1991-2010\left(3.47 \mathrm{Gta}^{-1}\right)$ is $31 \%$ higher than for the period 1971-90 (2.65 Gta ${ }^{-1}$; Van As and others, 2014). The magnitude of this increase in runoff could feasibly be scaled to changes in CWD even greater than the maximum $20 \%$ step change investigated here (Fig. 8). Given the existence of this scale of multi-decadal variability, it is therefore realistic to suggest that runoff-driven changes to CWD were potentially the primary driver of KNS's retreat from its LIAmax to the 1859 position.

It has also been established that the $12.5 \mathrm{~km}$ pinning point identified in multiple model runs is likely to be real, and not the result of uncertainty in fjord topography (Appendix C). The lack of evidence for terminus stabilization at this location from either observations or geomorphology therefore suggests that the terminus of KNS was able to bypass this pinning point in response to the magnitude of forcing it experienced as it retreated. Unfortunately, at present there is a significant lack of summer temperature observations, or proxy data with sufficiently high temporal resolution/accuracy for the period relating to this study. Therefore it is not possible to attribute the observed terminus retreat to any specific known climate change in Greenland.

\section{CONCLUSIONS}

KNS is shown to have retreated by at least $12 \mathrm{~km}$ in one or two phases from its LIAmax to 1859. Utilizing historical sources, we place KNS at its LIAmax in 1761; it had retreated $\sim 5 \mathrm{~km}$ from this position by 1808 . This is earlier than any other known post-LIAmax glacier retreat in Greenland. Map and early photographic evidence provide a range of possible terminus positions for 1859 within the 1920 Stade moraine limit. Geomorphology indicates rapid retreat of at least $7 \mathrm{~km}$ to the 1859 terminus following a retreat from LIAmax to the 1808 terminus position (twophase retreat scenario). However, it is possible KNS retreated in a single phase to the 1859 position, and the terminus was observed in 1808 during this retreat. This provides evidence for at least one and potentially two significant post-LIAmax retreats of a major Greenlandic TWG occurring in the early 19th and potentially late 18th centuries. The timing of this predates the post-LIAmax retreat of Jakobshavn Isbræ by at least 43 years, though possibly up to 113 years (Csatho and others, 2008). This highlights the asynchroneity of TWG terminus responses from their LIAmax, and the similarity to asynchronous behaviour of 21st-century TWG dynamics (McFadden and others, 2011; Moon and others, 2012). This contrasting behaviour also demonstrates the risk of using dated maximum terminus positions from individual TWGs as indicators of a regional LIA maximum.

Modelling results suggest that terminus stability is largely insensitive to SMB-driven ice thickness changes, while SM is likely to have had a minor or modulating effect on the overall terminus retreat over centennial timescales. By contrast, the modelled glacier is very sensitive to changes in CWD, that are capable of driving a retreat of KNS from its LIAmax to its 1859 configuration. The changes in CWD required to drive the retreat are also within the range of multi-decadal variability of more recent surface runoff values derived from high-resolution SMB modelling (Van As and others, 2014). This highlights runoff-driven changes 
to CWD as a likely potential driver of terminus retreat between the LIAmax and 1859.

Given the need to establish the centennial-timescale controls on TWG variability (and hence ice-sheet response, and likely sea-level change), high-resolution, high-quality, quantitative proxy records of climate forcing are needed to allow adequate evaluation of centennial records of glacier fluctuations, such as presented here. These include reconstructions of local summer air temperature variability (e.g. D'Andrea and others, 2011), runoff (e.g. Kamenos and others, 2012) and fjord hydrography (e.g. Lloyd and others, 2011). The latter is potentially significant for glaciers such as KNS that drain into fjords with a shallow fjord mouth sill (Mortensen and others, 2011, 2013; Straneo and others, 2012). Such proxy records, alongside instrumental records and longer-term reconstructions of glacier behaviour back to their Little Ice Age maxima (and where possible beyond), would provide significant improvements to our understanding of TWG response over the next 100-200 years.

\section{ACKNOWLEDGEMENTS}

We thank two anonymous reviewers for comments that helped to improve the manuscript. Nora Weitz (University of Maine, USA) is thanked for assistance with translating passages of German, and Christian Koch Madsen (National Museum of Denmark, Copenhagen) for help with tracking down images of KNS. RACMO2.1 data were provided by Jan van Angelen and Michiel van den Broeke of the Institute for Marine and Atmospheric Research Utrecht (IMAU), The Netherlands. This research was financially supported by J.L.'s PhD funding, UK Natural Environment Research Council (NERC) grant No. NE/I528742/1. Support for F.M.N. was provided by the Conoco-Phillips/Lundin Northern Area Program CRIOS (Calving Rates and Impact on Sea Level) project.

\section{REFERENCES}

Alley RB and 13 others (2010) History of the Greenland Ice Sheet: paleoclimatic insights. Quat. Sci. Rev., 29(15-16), 1728-1756 (doi: 10.1016/j.quascirev.2010.02.007)

Bamber JL, Layberry RL and Gogineni SP (2001) A new ice thickness and bed data set for the Greenland ice sheet. 1. Measurement, data reduction, and errors. J. Geophys. Res., 106(D24), 33 773-33 780 (doi: 10.1029/2001JD900054)

Benn DI, Hulton NRJ and Mottram RH (2007) 'Calving laws', 'sliding laws' and the stability of tidewater glaciers. Ann. Glaciol., 46, 123-130 (doi: 10.3189/172756407782871161)

Bevan SL, Luckman AJ and Murray T (2012) Glacier dynamics over the last quarter of a century at Helheim, Kangerdlugssuaq and 14 other major Greenland outlet glaciers. Cryosphere, 6(5), 923-937 (doi: 10.5194/tc-6-923-2012)

Bjørk AA and 8 others (2012) An aerial view of 80 years of climaterelated glacier fluctuations in southeast Greenland. Nature Geosci., 5(6), 427-432 (doi: 10.1038/ngeo1481)

Box JE and Decker DT (2011) Greenland marine-terminating glacier area changes: 2000-2010. Ann. Glaciol., 52(59), 91-98 (doi: 10.3189/172756411799096312)

Box JE and 11 others (2013) Greenland Ice Sheet mass balance reconstruction. Part I: net snow accumulation (1600-2009). J. Climate, 26(11), 3919-3934 (doi: JCLI-D-12-00373.1)

Briner JP, Stewart HAM, Young NE, Philipps W and Losee S (2010) Using proglacial-threshold lakes to constrain fluctuations of the Jakobshavn Isbræ ice margin, western Greenland, during the Holocene. Quat. Sci. Rev., 29(27-28), 3861-3874 (doi: 10.1016/j.quascirev.2010.09.005)
Colgan W, Pfeffer WT, Rajaram H, Abdalati W and Balog J (2012) Monte Carlo ice flow modeling projects a new stable configuration for Columbia Glacier, Alaska, c. 2020. Cryosphere, 6(6), 1395-1409 (doi: 10.5194/tc-6-1395-2012)

Cook S, Zwinger T, Rutt IC, O'Neel S and Murray T (2012) Testing the effect of water in crevasses on a physically based calving model. Ann. Glaciol., 53(60 Pt 1), 90-96 (doi: 10.3189/ 2012AoG60A107)

Cook S and 6 others (2013) Modelling environmental influences on calving at Helheim Glacier, East Greenland. Cryos. Discuss., 7(5), 4407-4442 (doi: 10.5194/tcd-7-4407-2013)

Crantz D (1820) The history of Greenland including an account of the mission carried on by the united brethren in that country: from the German of David Crantz, 2 vols. Longman, Hurst, Rees, Orme and Brown, London

Csatho B, Schenk T, Van der Veen CJ and Krabill WB (2008) Intermittent thinning of Jakobshavn Isbræ, West Greenland, since the Little Ice Age. J. Glaciol., 53(184), 131-144 (doi: 10.3189/002214308784409035)

Cuffey KM and Paterson WSB (2010) The physics of glaciers, 4th edn. Butterworth-Heinemann, Oxford

D'Andrea WJ, Huang Y, Fritz SC and Anderson NJ (2011) Abrupt Holocene climate change as an important factor for human migration in West Greenland. Proc. Natl Acad. Sci. USA (PNAS), 108(24), 9765-9769 (doi: 10.1073/pnas.1101708108)

Enderlin EM and Howat IM (2013) Submarine melt rate estimates for floating termini of Greenland outlet glaciers (2000-2010). J. Glaciol., 59(213), 67-75 (doi: 10.3189/2013JoG12J049)

Enderlin EM, Howat IM and Vieli A (2013) The sensitivity of flowline models of tidewater glaciers to parameter uncertainty. Cryosphere, 7(5), 1579-1590 (doi: 10.5194/tc-7-1579-2013)

Ettema J and 6 others (2009) Higher surface mass balance of the Greenland ice sheet revealed by high-resolution climate modelling. Geophys. Res. Lett., 36(12), L12501 (doi: 10.1029/ 2009GL038110)

Fowler AC (2010) Weertman, Lliboutry and the development of sliding theory. J. Glaciol., 56(200), 965-972 (doi: 10.3189/ 002214311796406112)

Giesecke KL (1910) Mineralogisches Reisejournal über Grönland 1806-13. Medd. Grønl., 35

Gogineni S and 9 others (2001) Coherent radar ice thickness measurements over the Greenland ice sheet. J. Geophys. Res., 106(D24), 33 761-33 772 (doi: 10.1029/2001JD900183)

Holland DM, Thomas RH, De Young B, Ribergaard MH and Lyberth B (2008) Acceleration of Jakobshavn Isbræ triggered by warm subsurface ocean waters. Nature Geosci., 1(10), 659-664 (doi: 10.1038/ngeo316)

Jamieson SSR and 6 others (2012) Ice-stream stability on a reverse bed slope. Nature Geosci., 5(11), 799-802 (doi: 10.1038/ ngeo1600)

Joughin I, Smith BE and Holland DM (2010a) Sensitivity of 21st century sea level to ocean-induced thinning of Pine Island Glacier, Antarctica. Geophys. Res. Lett., 37(20), L20502 (doi: 10.1029/2010GL044819)

Joughin I, Smith BE, Howat IM, Scambos T and Moon T (2010b) Greenland flow variability from ice-sheet-wide velocity mapping. J. Glaciol., 56(197), 415-430 (doi: 10.3189/ 002214310792447734)

Kamenos NA, Hoey TB, Nienow P, Fallick AE and Claverie T (2012) Reconstructing Greenland ice sheet runoff using coralline algae. Geology, 40(12), 1095-10098 (doi: 10.1130/G33405.1)

Kleinschmidt S (1859) Godthåbs distrikt (hertil en Navneliste). (Map No. KBK Netpublikation RI000074) Copenhagen

Larsen NK, Kjær KH, Olsen J, Funder S, Kjeldsen KK and NørgaardPedersen N (2011) Restricted impact of Holocene climate variations on the southern Greenland Ice Sheet. Quat. Sci. Rev., 30(21-22), 3171-3180 (doi: 10.1016/j.quascirev.2011.07.022)

Lea JM, Mair DWF and Rea BR (2014) Evaluation of existing and new methods of tracking glacier terminus change. J. Glaciol., 60(220), 323-332 
Lloyd J and 6 others (2011) A 100 yr record of ocean temperature control on the stability of Jakobshavn Isbræ, West Greenland. Geology, 39(9), 867-870 (doi: 10.1130/G32076.1)

McFadden EM, Howat IM, Joughin I, Smith BE and Ahn Y (2011) Changes in the dynamics of marine terminating outlet glaciers in west Greenland (2000-2009). J. Geophys. Res., 116(F2), F02022 (doi: 10.1029/2010JF001757)

Mercer JH (1961) The estimation of the regimen and former firn limit of a glacier. J. Glaciol., 3(30), 1053-1062

Moon T and Joughin I (2008) Changes in ice front position on Greenland's outlet glaciers from 1992 to 2007. J. Geophys. Res., 113(F2), F02022 (doi: 10.1029/2007JF000927)

Moon T, Joughin I, Smith B and Howat I (2012) 21st-century evolution of Greenland outlet glacier velocities. Science, 336(6081), 576-578 (doi: 10.1126/science.1219985)

Morlighem M, Rignot E, Seroussi H, Larour E, Ben Dhia $\mathrm{H}$ and Aubry D (2011) A mass conservation approach for mapping glacier ice thickness. Geophys. Res. Lett., 38(19), L19503 (doi: 10.1029/2011GL048659)

Mortensen J, Lennert K, Bendtsen J and Rysgaard S (2011) Heat sources for glacial melt in a sub-Arctic fjord (Godthåbsfjord) in contact with the Greenland Ice Sheet. J. Geophys. Res., 116(C1), C01013 (doi: 10.1029/2010JC00652)

Mortensen J and 6 others (2013) On the seasonal freshwater stratification in the proximity of fast-flowing tidewater outlet glaciers in a sub-Arctic sill fjord. J. Geophys. Res., 118(3), 1382-1395 (doi: 10.1002/jgrc.20134)

Murray T and 10 others (2010) Ocean regulation hypothesis for glacier dynamics in southeast Greenland and implications for ice sheet mass changes. J. Geophys. Res., 115(F3), F03026 (doi: 10.1029/2009JF001522)

Nick FM, Vieli A, Howat IM and Joughin I (2009) Large-scale changes in Greenland outlet glacier dynamics triggered at the terminus. Nature Geosci., 2(2), 110-114 (doi: 10.1038/ngeo394)

Nick FM, Van der Veen CJ, Vieli A and Benn DI (2010) A physically based calving model applied to marine outlet glaciers and implications for the glacier dynamics. J. Glaciol., 56(199), 781-794 (doi: 10.3189/002214310794457344)

Nick FM and 8 others (2012) The response of Petermann Glacier, Greenland, to large calving events, and its future stability in the context of atmospheric and oceanic warming. J. Glaciol., 58(208), 229-239 (doi: 10.3189/2012JoG11J242)

Nick FM and 7 others (2013) Future sea-level rise from Greenland's major outlet glaciers in a warming climate. Nature, 497(7448), 235-238 (doi: 10.1038/nature12068)

Nye JF (1957) The distribution of stress and velocity in glaciers and ice-sheets. Proc. R. Soc. London, Ser. A, 239(1216), 113-133 (doi: 10.1098/rspa.1957.0026)

Rignot E, Koppes M and Velicogna I (2010) Rapid submarine melting of the calving faces of West Greenland glaciers. Nature Geosci., 3(3), 141-218 (doi: 10.1038/ngeo765)

Rignot E, Fenty I, Menemenlis D and Xu Y (2012) Spreading of warm ocean waters around Greenland as a possible cause for glacier acceleration. Ann. Glaciol., 53(60 Pt 2), 257-266 (doi: 10.3189/2012AoG60A136)

Rink H (1856) Sydgrønlands nordlige distrikter. (Map No. KBK Netpublikation RI000095) Copenhagen

Sciascia R, Straneo F, Cenedese C and Heimbach P (2013) Seasonal variability of submarine melt rate and circulation in an East Greenland fjord. J. Geophys. Res., 118(C5), 2492-2506 (doi: 10.1002/jgrc.20142)

Straneo F and 7 others (2010) Rapid circulation of warm subtropical waters in a major glacial fjord in East Greenland. Nature Geosci., 3(33), 182-186 (doi: 10.1038/ngeo764)

Straneo F and 8 others (2012) Characteristics of ocean waters reaching Greenland's glaciers. Ann. Glaciol., 53(60 Pt 2), 202-210 (doi: 10.3189/2012AoG60A059)

Thomas RH (2004) Force-perturbation analysis of recent thinning and acceleration of Jakobshavn Isbræ, Greenland. J. Glaciol., 50(168), 57-66 (doi: 10.3189/172756504781830321)
Thorhallesen E (1776) Efterretning om rudera eller levninger af de gamle nordmœends og islœenderes bygninger paa Grønlands vester-side, tilligemed et anhang om deres undergang sammesteds. Trykt hos A.F. Stein, Copenhagen

Van As D, Hubbard AL, Hasholt B, Mikkelsen AB, Van den Broeke MR and Fausto RS (2012) Large surface meltwater discharge from the Kangerlussuaq sector of the Greenland ice sheet during the record-warm year 2010 explained by detailed energy balance observations. Cryosphere, 6(1), 199-209 (doi: 10.5194/tc-6-199-2012)

Van As D and 11 others (2014) Increasing meltwater discharge from the Nuuk region of the Greenland ice sheet and implications for mass balance (1960-2012). J. Glaciol., 60(220), 314-322

Van den Broeke $M$ and 8 others (2009) Partitioning recent Greenland mass loss. Science, 326(5955), 984-986 (doi: 10.1126/science.1178176)

Van der Veen CJ and Whillans IM (1996) Model experiments on the evolution and stability of ice streams. Ann. Glaciol., 23, 129-137

Vieli A and Nick FM (2011) Understanding and modelling rapid dynamic changes of tidewater outlet glaciers: issues and implications. Surv. Geophys., 32(4-5), 437-458 (doi: 10.1007/ s10712-011-9132-4)

Vinther BM, Andersen KK, Jones PD, Briffa KR and Cappelen J (2006) Extending Greenland temperature records into the late eighteenth century. J. Geophys. Res., 111(D11), D11105 (doi: 10.1029/2005JD006810)

Weidick A (1959) Glacial variations in West Greenland in historical time. Part I. South West Greenland. Bull. Grønl. Geol. Unders. 18

Weidick A (1968) Observations on some Holocene glacier fluctuations in West Greenland. Medd. Grønl. 165(6)

Weidick A and Bennike O (2007) Quaternary glaciation history and glaciology of Jakobshavn Isbræ and the Disko Bugt region, West Greenland: a review. Geol. Surv. Den. Greenl. Bull. 14

Weidick A and Citterio M (2011) Correspondence. The ice-dammed lake Isvand, West Greenland, has lost its water. J. Glaciol., 57(201), 186-188 (doi: 10.3189/002214311795306600)

Weidick A, Bennike O, Citterio M and Nørgaard-Pedersen N (2012) Neoglacial and historical glacier changes around Kangersuneq Fjord in southern West Greenland. Geol. Surv. Den. Greenl. Bull. 27

\section{APPENDIX A: MODEL DESCRIPTION}

The model used in this study is designed to simulate the behaviour of tidewater outlet glaciers, and is explained in full detail in Nick and others (2010). It employs a simple, physically based, nonlinear effective pressure sliding law, where the depth-integrated driving stress is balanced by longitudinal stress gradients, basal and lateral drag (Van der Veen and Whillans, 1996; Fowler, 2010). These are represented by the first, second and third terms respectively on the right-hand side of Eqn (A1), with the driving stress represented by the left-hand term:

$$
\begin{aligned}
\rho_{\mathrm{i}} g H \frac{\partial H}{\partial x}= & 2 \frac{\partial}{\partial x}\left(H \nu \frac{\partial U}{\partial x}\right)-\mu A_{\mathrm{s}}\left[\left(H-\frac{\rho_{\mathrm{p}}}{\rho_{\mathrm{i}}} D\right) U\right]^{1 / m} \\
& -\frac{2 H}{W}\left(\frac{5 U}{\lambda A W}\right)^{1 / m}
\end{aligned}
$$

where $\rho_{\mathrm{i}}$ is density of ice, $\rho_{\mathrm{p}}$ is density of the proglacial water body, $g$ is gravitational acceleration, $x$ is the along-flow distance, $H$ is ice thickness, $D$ is depth of ice below the surface of the proglacial water body, $A_{\mathrm{s}}$ is bed roughness parameter, $A$ is temperature-dependent rate factor $(4.5 \times$ $10^{-17} \mathrm{~Pa}^{-3} \mathrm{a}^{-1}$, corresponding to ice at $-5^{\circ} \mathrm{C}$ (Cuffey and 
Paterson, 2010)), $W$ is glacier width, $\nu$ is effective viscosity (dependent on the strain rate) and $m$ is friction exponent. This sliding law allows the modelled glacier to replicate the velocity profiles that are often observed approaching marine termini, and thus provides a good representation of realistic sliding (Nick and others, 2010, 2013; Vieli and Nick, 2011; Jamieson and others, 2012). Constant and parameter values used in the model are outlined in Table 1.

Variations in basal and lateral friction due to meltwater supply can also potentially be modelled using the friction parameters $\mu$ and $\lambda$ (Nick and others, 2010, 2012, 2013). However, both are given a constant value of 1 in all model runs shown, since this has primarily been suggested to be most significant over sub-annual, rather than multi-annual to decadal, timescales (Howat and others, 2010; Nick and others, 2010, 2012, 2013; Vieli and Nick, 2011).

The model employs a full-depth calving criterion, calculating the penetration depth of both surface and basal crevasses within a field of closely spaced crevasses (Nye, 1957; Benn and others, 2007). Calving occurs when the surface and basal crevasses combined penetrate the full ice thickness (Nick and others, 2010). Where water ponds in crevasses there is the potential for it to force deeper penetration compared to a dry crevasse, according to

$$
d_{\mathrm{s}}=\frac{2}{\rho_{\mathrm{i}} g}\left(\frac{\dot{\varepsilon}_{x x}}{A}\right)^{1 / n}+\frac{\rho_{\mathrm{w}}}{\rho_{\mathrm{i}}} d_{\mathrm{w}}
$$

where $d_{\mathrm{s}}$ is depth of surface crevasse, $\dot{\varepsilon}_{x x}$ is longitudinal stretching rate, $n$ is Glen's flow law exponent and $d_{w}$ is crevasse water depth. For a given flow regime, greater values of $d_{w}$ can therefore instigate higher calving rates that in turn drive retreat.

Basal crevasse heights are also included in calculations of cumulative crevasse penetration, according to

$$
d_{\mathrm{b}}=\frac{2 \rho_{\mathrm{i}}}{\rho_{\mathrm{p}}-\rho_{\mathrm{i}}}\left(\frac{\dot{\varepsilon}_{x x}}{A}\right)^{1 / n}\left(\frac{1}{\rho_{\mathrm{i}} g}-H_{\mathrm{ab}}\right)
$$

where $H_{\mathrm{ab}}$ is height above buoyancy of a given ice thickness, calculated as

$$
H_{\mathrm{ab}}=H-\frac{\rho_{\mathrm{p}}}{\rho_{\mathrm{i}}} D
$$

This full-depth calving criterion is employed given that instances of full-depth calving behaviour were observed at KNS during fieldwork conducted in August 2011.

SM is applied uniformly across the entire width of the grounding line. Volumetric rates of $\mathrm{SM}\left(\right.$ e.g. $\mathrm{km}^{3} \mathrm{a}^{-1}$ ) are also prescribed within the model rather than linear melt rates per time-step (e.g. $\mathrm{md}^{-1}$ ). This is because application of the latter to a 1-D model will result in SM volume being partially dependent on the glacier width. Volumetric rates provide internal consistency between model runs for each time-step and location in the modelled fjord. Constant SM values ranged from 0 to $1.5 \mathrm{~km}^{3} \mathrm{a}^{-1}\left(0.1 \mathrm{~km}^{3} \mathrm{a}^{-1}\right.$ intervals $)$. The latter is equivalent to SM rates of 0 to $\sim 5.25 \mathrm{~m} \mathrm{~d}^{-1}$ with increments of $\sim 0.36 \mathrm{~m} \mathrm{~d}^{-1}$. This covers the range of values up to $150 \%$ of those that have so far been observed for termini in western Greenland (Rignot and others, 2012; Enderlin and Howat, 2013).

To allow direct comparison, previously published daily linear SM rate values $\left(\mathrm{m} \mathrm{d}^{-1}\right)$ were multiplied by 365.25 to scale them up to units of $\mathrm{m} \mathrm{a}^{-1}$, before being converted to volumetric values. The conversion to volumetric melt rates was achieved by multiplying the annual linear SM values by

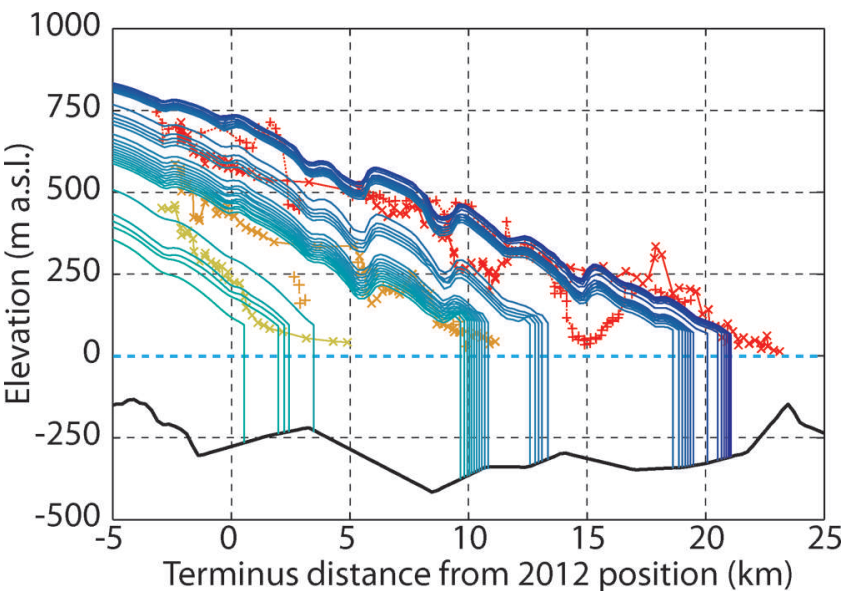

Fig. 9. Surface elevation profile evolution of the modelled glacier superimposed on the reconstructed elevation profiles for LIAmax (red), 1920 Stade (orange) and 1985 (yellow). Each modelled profile shown represents $1 \mathrm{~m}$ increments in CWD every fifth model year.

KNS's contemporary glacier width $(\sim 5 \mathrm{~km})$ and fjord depth at the terminus $(\sim 225 \mathrm{~m})$. As an approximation, these SM volume values were then halved, to reflect that the majority of SM occurs during summer only, driven by subglacial runoff (Sciascia and others, 2013). These equate to volumetric SM range estimates for KNS of between $(0.15 \pm 0.05)$ and $(0.8 \pm 0.15) \mathrm{km}^{3} \mathrm{a}^{-1}$ (Rignot and others, 2012; Enderlin and Howat, 2013). Within this range, the SM value for KNS has been suggested to be low compared to other Greenlandic glaciers, since fjord bathymetry is thought to limit the influence of ocean waters on fjord water temperature (Mortensen and others, 2011, 2013; Straneo and others, 2012).

\section{APPENDIX B: MODEL TUNING}

A variety of basal sliding scenarios are explored during tuning by varying the basal roughness parameter $A_{\mathrm{s}}$. For simplicity, the catchment is split into two different zones where $A_{\mathrm{s}}$ is set to two different values. These comprise a rougher upstream and smoother downstream zone. Five different transition positions between these two zones are modelled to establish how this may affect model behaviour (especially potential effects on modelled elevation profiles). The boundary positions investigated between these zones were positioned $5-55 \mathrm{~km}$ from the 2012 terminus position at $10 \mathrm{~km}$ intervals. On interferometric synthetic aperture radar (InSAR) velocity maps the latter position marks the approximate location of where rapid ice flow begins (Joughin and others, 2010b), providing an intuitive upstream limit to the transition between the higher and lower basal roughness values. Thirty different basal sliding scenarios were evaluated, with the feasibility of each evaluated through comparison to glacier elevation profiles reconstructed from the geomorphology (e.g. Fig. 9).

By applying uniform basal roughness values we aim to avoid circular reasoning that would arise by tuning basal roughness values to predispose KNS to stabilizing/retreat at sections where pinning points/retreats have occurred. This allows robust interrogation of model results, making as few assumptions as possible regarding basal roughness. The sensitivity of each modelled glacier to retreat under specific basal roughness scenarios was tested by increasing $d_{w}$ 


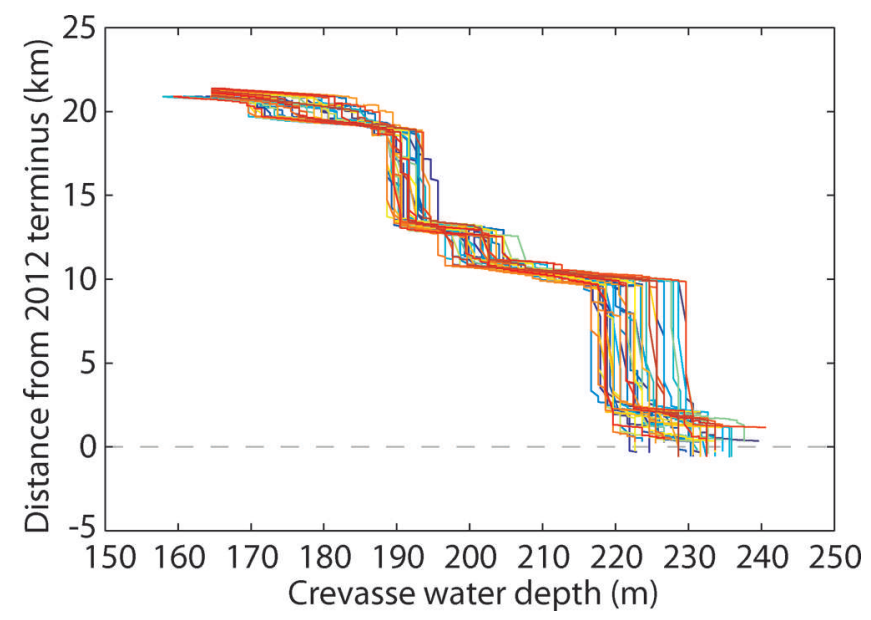

Fig. 10. Example of terminus sensitivity to random changes in unknown sections of fjord bathymetry along the entire length of the fjord. Results are shown for the retreat pattern of the modelled glacier in response to $1 \mathrm{~m}$ increments of CWD every fifth model year, for 50 different bed configurations.

incrementally. For each scenario the post-spin-up value of $d_{\mathrm{w}}$ was increased by $1 \mathrm{~m}$ every 5 model years until the terminus retreated beyond the 2012 terminus position, or $d_{w}$ exceeded $250 \mathrm{~m}$. The latter condition is applied since sections of the fjord are $<250 \mathrm{~m}$ in depth, meaning that in these regions the terminus is fully grounded and its position will be defined almost solely as a function of $d_{w}$. Where this occurs and the fjord continues to shallow this could potentially force the creation of unrealistic freeboard heights at modelled termini.

Figure 9 is an example output of the sensitivity tests, showing the profile evolution of the basal roughness configuration used in this study.

\section{APPENDIX C: BED SENSITIVITY}

Previously published work has established that model results of tidewater glaciers can be sensitive to uncertainties in fjord bathymetry (Enderlin and others, 2013). To evaluate whether the uncertainty in fjord bathymetry significantly affects modelled terminus behaviour, sensitivity tests were conducted. This involved randomly varying bed elevation where fjord topography is unknown over blocks of three gridcells $(\sim 750 \mathrm{~m})$, across a vertical range of $\pm 50 \mathrm{~m}$, before then being smoothed over the same distance to avoid step changes in topography. Three sets of experiments were run, (1) varying the bed downstream of the 1920 Stade maximum, holding the downstream section of the fjord constant, (2) varying the bed upstream of the 1920 Stade maximum, holding the upstream section of the fjord constant, and (3) varying the bed downstream of the 2012 terminus position. This evaluates the impact of bed uncertainty, and potentially the section of the fjord where this is important. Each experiment was run for 50 different bed configurations.

Results demonstrate that unknown sections of fjord topography do not significantly affect the large-scale retreat behaviour of KNS (e.g. Fig. 10). Pinning points identified by the model are therefore suggested to be real, rather than artefacts of fjord topography uncertainty. 